\title{
Can Autonomous Art Change the World?
}

On Heidegger's Understanding of the Political Significance of Art

Andrea Kern

\section{Three Models of the Aesthetic}

Since Kant's aesthetics, aesthetics has been divided into two competing traditions: On the one hand, there is the program of autonomous aesthetics in Kant's sense. According to this tradition, works of art are meaningful artefacts that are structurally distinct from other meaningful artefacts in that they are not aimed at having any specific meaning and resist any specification of such a meaning. On the other hand, one finds the program of hermeneutic aesthetics. According to this program, the idea of "l'art pour l'art" rests on a misinterpretation of the relation between the aesthetic and the non-aesthetic. Against autonomous aesthetics, it can be objected that there cannot, in principle, be "l'art pour l'art". Every meaningful artefact is in principle aimed at fulfilling a meaning.

However, the proponents of hermeneutic aesthetics disagree about what the meaning of the aesthetic is exactly. So hermeneutic aesthetics itself divides into the aesthetics of truth, which has its roots in Hegel and continues through Gadamer, and political aesthetics, whose paradigmatic proponent is certainly Bertolt Brecht. The central idea of the aesthetics of truth is that the meaning of a work of art consists in the presentation of fundamental truths. These can be "eternal" truths or truths that are characteristic of a certain historical period. The central idea of political aesthetics is that the meaning of a work of art is determined by the fact that it enlightens the viewer about the political situation in a way that changes his thinking and his actions. Political aesthetics is not only concerned with truth, but also with change.

These three models of aesthetics obviously correspond to three different conceptions of the aesthetic viewer: Autonomous aesthetics understands the viewer primarily as the subject of self-sufficient contemplation, the aesthetics of truth understands the viewer primarily as an epistemic subject, and political aesthetics regards him as the subject of a transform- 
ation. Contemplation, knowledge, transformation: since Kant, the aesthetic viewer has moved within this aesthetic triangle.

There have been attempts in 2oth century aesthetics to combine all three conceptions of the aesthetic with one another. Adorno tried to combine autonomous aesthetics with the aesthetics of truth. Heidegger, in his essay Der Ursprung des Kunstwerkes, tried to show that all three models, the contemplative, the cognitive, and the transformative, are elements of one single united aesthetic model. In what follows, I want to focus on Heidegger's attempt to reach such a synthesis. Art would then be everything at the same time: a place of contemplation, a place of knowledge, and a place of transformation.

In what follows, I would like to ask whether and how Heidegger achieved this synthesis. I will show that Heidegger's thesis about the interconnection of aesthetic autonomy, truth, and change can be interpreted in two different ways. These two interpretations are diametrically opposed insofar as they are connected with two fundamentally different conceptions of what truth and, correspondingly, the transformative character of art consist in. ${ }^{1}$

\section{The Autonomy of Art}

In his essay on the work of art, Heidegger argues for the following three claims:

1. Art has a meaningful way of being which cannot be reduced to the way of being of objects of use. Let us call this the thesis of autonomy.

2. The essence of art consists in "truth's putting-itself-into-the-work" (Sich-ins-Werk-Setzen der Wahrheit). ${ }^{2}$ Let us call this the thesis of truth.

3. The essence consists in a "foundation of truth" (Stiftung der Wahrheit), which "grounds history" (die Geschichte gründet). ${ }^{3}$ Let us call this the thesis of transformation.

According to Heidegger, all three theses are essentially connected with one another in the following way: The second thesis, the thesis of truth, is supposed to be an argument for the first thesis, the thesis of autonomy. The third thesis, the thesis of transformation, is supposed to follow from the second thesis, the thesis of truth. This would mean that art has an autonomous way of being because it is a place where truth puts itself into the work. And because it is a place where truth puts itself into the work, it is supposed to follow that it "grounds history" and causes a change in the world and in the subjects. 
Let us first take a look at the thesis of autonomy: Heidegger begins his thoughts on art with a specification of the ontology of a work of art. The concept of a work of art can be understood neither from the concept of a thing nor from the concept of a tool $(\mathrm{Zeug})$. The concept of a work of art designates a third ontological category over and above things and tools. Hence, by saying that van Gogh's painting, which Heidegger interprets in his essay, is a work of art, we are saying that this object belongs to a realm of objects whose way of being is irreducible to the way of being of those objects that are tools or things.

Heidegger determines the special way of being of a work of art by calling it "truth's putting itself into the work". ${ }^{4}$ Hence, Heidegger wants to say that works of art are only real in the way of a process of truth putting itself into the work. We should be aware how radical this procedural specification of art is: Heidegger does not say that works of art are in the first place existing objects, in which an additional process of truth putting itself into the work takes place. He says that works of art are real only in the way of this process. If no such process of truth's putting itself into the work takes place, then there is no work of art. $^{5}$

According to Heidegger, the reason that works of art are autonomous entities which have their own way of being is that in them, truth is putting itself into the work. Therefore, the point of the thesis of truth is to explain and to give reasons for what it means that works of art are autonomous entities. Art is autonomous exactly because its way of being consists in a process, in a process of truth putting itself into the work. What does that mean?

\section{The Essence of Truth: Clearing and Concealment}

First, therefore, let us ask what Heidegger means by truth. In his essay on the work of art he says: The essence of truth consists in a conflict between clearing (Lichtung) and concealment (Verbergung). We can figure out what exactly this is supposed to mean by looking at Heidegger's critique, since Being and Time, of the traditional concept of truth. I understand Heidegger's critique as follows: The understanding of truth according to which truth is a predicate which we use to attribute a property to a proposition, namely the property of agreeing with the stated fact, is a derivative understanding of the concept of truth. It is not a false understanding, we can talk this way, but only if we keep the following in mind: in a fundamental sense, the concept of truth designates a predicate that we do not use to describe a property of our understanding as it refers to beings (auf Seiendes bezogen), but rather the "measure" of this understanding. ${ }^{6}$ But if this is the fundamental meaning of the concept of truth - truth as 
the measure of our understanding -, then the crucial question is: how is it possible that our understanding can have such a truth-oriented reference to beings? That is, how is it possible that "beings as they are" can be "giving the measure and be binding" in our understanding?7

The concept Heidegger uses in Being and Time to designate the prerequisite that is necessary for this, is the concept of disclosure (Erschlossenheit). ${ }^{8}$ In his essay on the work of art, he replaces this concept with the concept of clearing (Lichtung).

Beings as beings can only be, if they stand into and out of the cleared of this clearing. Only this clearing gives and guarantees us humans a passageway to beings that we ourselves are not and the access to those beings that we ourselves are. ${ }^{9}$

In his essay on the work of art, Heidegger connects the concept of clearing very closely with the concept of language. The "clearing of beings" takes place "in language". ${ }^{10}$ Because of this, we can describe the prerequisites for the truth-oriented character of our understanding, which Heidegger is referring to with the concept of clearing, in a first step as follows: To have at one's disposal a language and thereby to have at one's disposal an understanding of a meaningful totality of, as Heidegger says, "paths and references", ${ }^{11}$ is the prerequisite for beings, such as they are, to be the measure of our understanding. Heidegger also calls this meaningful totality which "gives the measure" for our individual performances of understanding, the world: ${ }^{12}$

The world is the opening openness of the wide paths of the simple and essential decisions in the fate of a historical people. ${ }^{13}$

It follows that the concept of world designates the formal correlate of what a human being or a whole people has already "disclosed in advance" when it is referring to beings. ${ }^{14}$

It is now crucial for Heidegger's understanding of art how he describes the way of being of this always already performed disclosing of the world that he now calls "clearing". He characterizes it by two features. First, it is essential to the clearing that it is performative. Second, it follows from this that the clearing is "in itself at the same time concealment". ${ }^{15}$ So because it is essential that the disclosing of world has a performative character, Heidegger wants to argue, a failure in the double form of notunderstanding ("failing") and error ("obstructing") is an essential part of the understanding of beings. The essence of truth therefore consists in a conflict between clearing and concealment. Heidegger calls this conflict the "primal conflict". Something like truth only exists in this conflict: "truth establishes [...] itself as conflict". ${ }^{16}$ 
Let us first clarify the first step: With the thesis of the performative character of our understanding of the world, Heidegger is rejecting the idea that the world is an object of our understanding that we can bring in front of us independently of and outside of individual performances of understanding of beings. ${ }^{17}$ The understanding of world, which is the prerequisite for the understanding of beings, is only in the performance of the understanding of beings:

The world is never an object that stands in front of us and can be looked at. World is that which never has the character of an object to which we are subjected. ${ }^{18}$

From this performative character of the understanding of world, Heidegger concludes that the concealment or the failing of the understanding of beings in the form of not-understanding and error is part of the essence of understanding. But why should this be so? This is so, Heidegger argues, because the understanding then rests on a ground that is at the same time an "abyss" (Ab-Grund). ${ }^{19}$

We can see what Heidegger's thesis means, when we see that it necessarily follows from how he characterizes the way of being of our understanding of the world as performance: If our understanding of the world is the performative prerequisite for our understanding of beings, which has its measure in these beings, this then means that our understanding of the world cannot give us, independently of beings, criteria that we can use as grounds for our understanding of beings. The grounds on the basis of which we decide to understand beings in this way or that, have to refer to the beings as they are. ${ }^{20}$ Such a way of referring to beings as they are is only possible if the beings are showing themselves to us as they are and are not presenting themselves to us differently from how they are. This means, however, that beings have to make it possible for us out of their own accord to have a ground for understanding them in this way and not in another. It follows that every decision of understanding rests on a ground that depends on something which the one who understands cannot provide himself with, that is, the beings revealing themselves. "Every decision," says Heidegger, "rests on something unaccomplished, concealed, deceiving". ${ }^{21}$ When we decide to understand beings in this way and not differently, then the truth of this decision does not just depend on something that we do: that we base our decision on a ground. Rather, the truth of this decision also depends on what beings do themselves: whether they give us a ground for such a decision by showing themselves as they are.

And because of that, grounds are abysses for Heidegger. Our understanding can fail because beings have to show themselves to us in order 
for us to be able to understand them, and because this showing-themselves can either be a revealing-themselves or a concealment. The fact that we can be deceived about beings is essentially due to the fact that beings can deceive us. "That beings as appearances can be deceptive is the condition for the fact that we can be deceived, not the other way around."22

\section{The Essence of Art: World and Earth}

In the light of this, let us now consider Heidegger's claim that the essence of art consists in a process of truth putting-itself-into-the-work, that is, of truth in the sense of its essence. Heidegger writes: "In the work of art truth is at work, so not just something true." ${ }^{23}$ That which is at work in the work of art, Heidegger wants to say, is not just simply a true understanding but a performance of understanding itself, in such a way that in this performance its conflict-structure is "revealed". ${ }^{24}$ The unity of the work of art therefore itself has to consist in a conflict. It consists, says Heidegger, "in disputing the conflict between world and earth". ${ }^{25}$

Just as every ordinary understanding is characterized by a conflict between clearing and concealment, as we have seen above, the work of art according to Heidegger is also characterized by a conflict. In contrast to the ordinary understanding, however, it is now supposed to be the case that the work of art does not simply perform this conflict, but performs it in such a way that it reveals this conflict at the same time. In the work of art, "this conflict is fixed into the form of the work and is revealed by it". ${ }^{26}$ In the work of art, the conflict that characterizes every understanding is supposed to be revealed.

How does the work of art do that? Heidegger says: The work of art performs the conflict in such a way that it sets up (aufstellen) a world and at the same time puts an earth there (herstellen). "By setting up a world and putting an earth there, the work is an incitement of this conflict." ${ }^{27}$

According to what has been said above about the concept of world, the work of art setting up a world means that the work of art puts in front of us this meaningful totality, the disclosing of which is the prerequisite for us to be able to understand beings. The work of art does this, Heidegger argues, by thereby putting an earth there in the sense of making it visible: "To put the earth there means: to bring it into the open as that which locks itself." ${ }^{28}$ What is meant by earth? "Earth", Heidegger says, is meant to designate exactly that "on which and in which the human being grounds its habitation". ${ }^{29}$ But what is that on which and in which the human being grounds its habitation? Heidegger calls it "the massiveness and heaviness of the stone", "the shining and darkening of the color", "the 
naming power of the word", or the "silent hardness of the wood" ${ }^{30}$ Thus Heidegger's claim is that by means of the very process that constitutes the work of art, the rock first arrives at "supporting and resting, and in that way first becomes a rock; [...] the colors arrive at shining, the sound at sounding, the word at saying". ${ }^{31}$

I think we can understand Heidegger's concept of earth as follows: In his book Kant and the Problem of Metaphysics, Heidegger argues that that on which and in which the human being grounds its habitation is nothing but the beings themselves (in contrast with Being and Time, where it is the world itself that does not yet have a ground in the earth). ${ }^{32}$ Beings are that which the human being in his attitude towards those beings always already finds to be there "as that, which supports him, on which he is dependent" ${ }^{33}$

In the essay on the work of art, he now interprets this thought in the following way. The fundamental beings, on which the human being is dependent, are the beings that make a world of meaning possible for him: that is, the meaningful beings or, as we can also say, the meaningful material. Earth is Heidegger's name for this meaningful material that underlies every meaningful totality. I.e. Heidegger's name for, I quote again, "the massiveness and heaviness of the stone", "the shining and darkening of the color", "the naming power of the word", or the "silent hardness of the wood".

Now, Heidegger claims that the unity between world and earth is a conflicted one. The reason is that whenever a meaningful totality opens itself to us - for example the world of the peasant woman, which Heidegger imagines in his contemplation of van Gogh's painting, ${ }^{34}$ or the world of the Greeks that opens itself up to us in the contemplation of a Greek temple - then this event rests on the fact that that which the work of art is made out of - stone, wood, ore, color, language, sound - is given to us as meaningful material. The colors have to shine, the words have to have naming power, the sound has to sound. However, we cannot turn these things into objects that we can understand, because for us this meaningful material is only what it is - that is, meaningful material - with reference to a world that is opened up.

The shining of the colors, the naming power of the words, designate that meaningful material, whose givenness is the prerequisite for the world of the peasant woman to be able to open itself up to us. But at the same time, this meaningful material is only given to us in exactly that process in which this world opens itself up to us. That means that we cannot pull this givenness of meaningful material, from which the world of the peasant woman opens itself up to us, into our understanding of this world. It only shows itself to us in the understanding of this world as that 
which always conceals itself. In that the colors are shining, we can understand the world of the peasant woman, but we cannot understand the shining of the colors. We can measure the wavelengths of the colors, but then their shining is gone and therefore there is no meaningful material given any longer. We can put the stone on a scale and measure its weight, but then we only bring its heaviness into the calculation of a weight "and the pressing down has withdrawn itself from us". ${ }^{35}$ There is no way of understanding that leads us from the stone that is simply at hand to its pressing down. And from the splotch of color that is simply at hand, no way of understanding leads us to its shining. "In this way, the earth lets every penetrating into it shatter on itself." ${ }^{\prime 36}$

In the contemplation of a work of art, we therefore always perform a double motion: A double motion between the understanding of that world which the work of art opens up and the not-understanding of the meaningful material which opens up this world..$^{37}$ It is exactly by performing such a double motion in the contemplation of a work of art that truth puts itself into the work for us. Through this double motion, the abyssstructure of our truth-oriented understanding becomes explicit for us.

\section{Art as Foundation of Truth: the Revolutionary Reading}

In the contemplation of a work of art, we have argued, it is revealed to us that our truth-oriented understanding is characterized by a conflict: a conflict between understanding and not understanding, between succeeding and failing. That art has something to do with truth therefore does not simply mean that it tells us something true about the world. It rather means that art tells us something about the essence of truth, about its conflict-structure.

Heidegger thinks that it follows from this characterization of the work of art as an entity whose autonomy consists in the fact that it puts truth in this sense into the work, that truth is thereby founded and history grounded. Whenever art happens, says Heidegger, "a push comes into history" ${ }^{38}$ How are we to understand this? And why should that be so?

In what follows, I will distinguish two readings of this thought. Each will attempt, in different ways, to give reasons for the connection between the truth of the work of art and its history-transforming character. I will call the first reading the revolutionary reading. Its main advocate is Richard Rorty. I will call the second reading the reflexive reading.

The revolutionary reading understands this thought as follows: works of art are entities that create a new language in the sense that they create new paths and references between concepts and propositions; and they 
thereby open up a new understanding of the world. In doing that, they provide new standards for which decisions of understanding about beings will from now on be meaningful or meaningless, right or wrong. ${ }^{39}$

With this characterization of the foundational idea, the revolutionary reading is trying to capture Heidegger's rhetoric of the upheaval and the enormous, which is impossible to miss in the essay on the work of art. Heidegger emphasizes again and again that the putting-itself-into-thework of the truth of the work of art is a process that "knocks open" an openness in which "everything is different than it otherwise is" and in which something shows itself to us that could "never be proved or derived" from the previous. ${ }^{40}$ According to the revolutionary reading, this rhetoric is supposed to be captured by identifying the idea of the work of art founding truth with the idea of the work of art setting up a world. That means that the setting up of a meaningful totality, which the work of art achieves, is itself already interpreted as the event that founds truth.

But this means that according to this reading, art is characterized by the fact that it tells us something true, something that is a true understanding of the world. The true thing that art tells us is therefore of a special kind: It is not the truth of a single proposition, as it befits our ordinary understanding. The issue is rather the truth of a whole understanding of the world. And yet this reading claims that that which connects art with truth consists in the fact that it has something true as its content.

If art has something to do with truth in the sense that it depicts a new understanding of the world, then its transformative character would consist in the fact that it leads the viewer to such a new understanding of the world, which gives history a "push".

But this reading of the connection between truth and historical and political change is contradictory to Heidegger's central characterization of art, according to which a work of art is not just simply about something true, but truth itself is at work: "In the work, truth is at work, therefore, not just something true."41 According to Heidegger, the autonomy of the work of art is grounded in the fact, not that art has something true as its content but that it has the "essence of truth", or, as Heidegger says at this point, "truth itself", as its content. And because the essence of truth has the structure of a conflict, the unity of the work of art must also have the structure of a conflict. The revolutionary reading, however, does not take this thought of a conflict, a conflict between world and earth, into account. It only looks at the one side of Heidegger's conception, namely, that the work of art sets up a world. But that the work of art only sets up this world in such a way that it puts an earth there at the same time, does not play 
any role in this reading. According to Heidegger, the autonomy of art, however, lies in exactly that double character of art.

As I mentioned in the beginning, it is Heidegger's program to make a synthesis possible: a synthesis between aesthetic autonomy, truth and world change. That means that if art has something to do with truth and world change then this has to be the case, according to Heidegger, exactly because art is autonomous. The revolutionary reading on the other hand can only connect art with truth and the idea of world change by giving up the idea of the autonomy of art. Because according to that reading, art is not structurally different from ordinary meaningful entities. It only differs from them by content: Art does not have, unlike ordinary meaningful entities, individual truths as its content, but the truth of a whole understanding of the world. This, however, means that the revolutionary reading does not confirm anything else but that which every pure aesthetics of autonomy claims over and over: The autonomy of art cannot be connected with the thought that art could have something to do with truth and world change. A contradiction exists between autonomy on the one hand and truth and world change on the other. If the revolutionary reading were correct, it would follow that Heidegger's program of a synthesis of aesthetic autonomy, truth, and world change failed.

\section{Art as Foundation of Truth: the Reflexive Reading}

I would like to claim, in contrast to this, that Heidegger succeeds at such a synthesis. But in order to see this, one has to reconstruct the truth-claim of art and correspondingly its transforming character differently than the revolutionary reading does. In what follows, I would like to call this the reflexive reading.

The reflexive reading rests primarily on Heidegger's fundamental characterization of the essence of art as an entity whose autonomy consists in the fact that the work of art puts a conflict into the work. So the work of art does not simply set up a world, but it sets up this world in exactly such a way that it performs a conflict with the earth and thereby makes this conflict visible. Of this conflict, Heidegger says that it is the conflict of truth itself, of truth in the sense of its essence. It therefore has to be crucial for the thought that art "founds" truth and thereby "grounds history", and that the work of art does not simply found truth by setting up a meaningful totality, but by making this meaningful totality visible as a moment of a conflict.

Therefore, if we want to account for Heidegger's thought that the foundation of truth should spring from the essence of art and not, as the revolutionary reading alleges, just one of its two essential traits - namely the 
setting up of a world - then the truth that it founds has to have exactly this conflict as its content. But then it follows that the truth that art founds has to be a reflexive truth: namely, the truth about the conflict-structure of our truth-oriented understanding itself. ${ }^{42}$

Art makes the conflict-structure of truth visible to us by showing that the totality of sense which is decisive for us here and now is one that does not have its ground in itself. By showing that this totality of sense has a ground which cannot be pulled into this totality of sense, it bestows on us, to put it traditionally, an awareness of our finitude: namely, a consciousness that we, as the beings as which we understand ourselves here and now, are dependent on something whose givenness we cannot provide ourselves with.

To come to know the truth about the structure of our truth-oriented understanding is an event that indeed changes our "ordinary relations to the world and to the earth". ${ }^{43}$ Art has an essentially transformative power. The transformative power that the experience of art has for our ordinary understanding, however, does not consist in the fact that we gain a different understanding of the world. It rather consists in this: by art making the structure of our understanding of the world clear to us, we gain a different attitude towards our understanding of the world.

It is not an essential part of the experience of art that through it, we understand the world differently. But it is an essential part of this experience that through it we understand our understanding of the world differently: we now understand that our understanding of the world has an in principle fragile character because by its nature it is dependent on factors which are beyond our control. Through art we gain an awareness that our understanding of the world rests on a ground which is not at our disposal, but on which we are dependent and which is beyond us.

Gaining such an awareness "grounds history" in a specific sense: not in the sense in which the revolutionary reading understands it, namely, that art produces subjects who have a new understanding of the world on the basis of which they create a new historical epoch. That art grounds history rather means, according to the reflexive reading, that it produces subjects who have an awareness of the ground of their own understanding of the world and therefore of history. That is, an awareness that their understanding of the world rests on a ground which escapes being at their understanding's disposal.

The revolutionary reading seems to me to be the prevalent way in which, in aesthetics, art's relation to truth is connected with its transforming character. But if one understands Heidegger the way the revolutionary reading does, one has to deny that art is autonomous. That is, one has to 
deny that it is made up in a way that is structurally different from other meaningful entities in that the meaningful material in art does not exhaust itself in being the carrier of a meaning.

If, however, one understands Heidegger in the way the reflexive reading does, then he really achieved a synthesis between aesthetic autonomy, truth and world change. Art, then, really is everything at the same time: it is autonomous, that is, its meaning-carrying material does not exhaust itself in that it is serviceable to a meaning; it has something to do with truth, namely, with the essence of truth and exactly because of this it has a transforming character.

The aesthetic viewer therefore does indeed play all three roles at the same time: he is someone who contemplates, someone who moves back and forth in his contemplation of the work of art between understanding and not-understanding. He is an epistemic subject, who comes to know the essence of truth. And he is someone who is being changed: a subject that exhausts itself in its present understanding of the world is changed into a subject which has an awareness of the fragility of its understanding of the world.

Autonomous art, truth, and change therefore form a unity. But this unity does not aim directly at changing the world, but it aims at a change in our relation to the world.

Translation from German: Sibylle Salewski

\section{Notes}

1. Some of the following material I have developed more extensively in my article "'Der Ursprung des Kunstwerkes'. Kunst und Wahrheit zwischen Stiftung und Streit", in: D. Thomä (ed.), Heidegger-Handbuch. Leben - Werk - Wirkung, Stuttgart 2003.

2. M. Heidegger, "Der Ursprung des Kunstwerkes", in: M. Heidegger, Holzwege. Gesamtausgabe Bd. 5, Frankfurt am Main 1975f, p. 21 (translation from German here as elsewhere: Sibylle Salewski).

3. Ibid. p. 65 .

4. Ibid. p. 21.

5. See for this G. Boehm, "Im Horizont der Zeit. Heideggers Werksbegriff und die Kunst der Moderne”, in: Walter Biemel/Friedrich-Wilhelm v. Herrmann (Hg.): Kunst und Technik. Frankfurt am Main 1989, p. 267.

6. M. Heidegger, Die Grundbegriffe der Metaphysik. Welt - Endlichkeit - Einsamkeit, in: Gesamtausgabe Bd. 20/30, Frankfurt am Main 1975 ff., p. 496.

7. Ibid., p. 497 
Andrea Kern

8. M. Heidegger, Sein und Zeit, Tübingen 1986 (16. Aufl.), p. 85 ff., 220

9. M. Heidegger, "Der Ursprung des Kunstwerkes", p. 40.

10. Ibid., p. 62

11. Ibid., p. 28.

12. M. Heidegger, Die Grundbegriffe der Metaphysik, p. 496.

13. M. Heidegger, "Der Ursprung des Kunstwerkes", p. 35.

14. See M. Heidegger, Sein und Zeit, p. 85.

15 M. Heidegger, “Der Ursprung des Kunstwerkes", p. 40

16 Ibid., p. 51.

17. See ibid., p. 41.

18. Ibid., p. 30.

19. See M. Heidegger, Beiträge zur Philosophie, in: Gesamtausgabe Bd. 65, Frankfurt am Main 1975ff., p. 379.

20. See J. Haugeland, “Truth and Finitude: Heidegger's Transcendental Existentialism”, in: M. Wrathall and J. Malpas (ed.), Heidegger, Authenticity, and Modernity, Cambridge Mass. 2000, especially pp. 69-77.

21. M. Heidegger, "Der Ursprung des Kunstwerkes", p. 42.

22. Ibid., p. 40.

23. Ibid., p. 43

24. Ibid., p. 57

25. Ibid., p. 36.

26. Ibid., p. 57.

27. Ibid., p. 36 .

28. Ibid., p. 33 .

29. Ibid., p. 28.

30. Ibid., p. 32, 51.

31. Ibid., p. 32.

32. See M. Heidegger, Sein und Zeit, p. 65, 87.

33. M. Heidegger, Kant und das Problem der Metaphysik, in: Gesamtausgabe Bd. 3, Frankfurt am Main 1975 ff., p. 228.

34. See M. Schapiro, "The Still Life as a Personal Object. A note on Heidegger and van Gogh", in: M. L. Simmel (ed.), The Reach of Mind, New York 1968, p. 203-209.

35. M. Heidegger, "Der Ursprung des Kunstwerkes", p. 33.

36. Ibid.

37. Ibid., p. 53 .

38. Ibid., p. 65 .

39. R. Rorty, "Heidegger wider die Pragmatisten", in: Neue Hefte für Philosophie 23, 1984, p. 1of.

40. M. Heidegger, “Der Ursprung des Kunstwerkes”, p. 59, 63.

41. Ibid., p. 43. 
42. See for this J. Derrida, La vérité en peinture, Paris 1978; Ch. Menke, Die Souveränität der Kunst. Ästhetische Erfahrung nach Adorno und Derrida, Frankfurt am Main 1991; R. Bernstein, The Fate of Art. Aesthetic Alienation from Kant to Derrida and Adorno, Pennsylvania 1992.

43. M. Heidegger, "Der Ursprung des Kunstwerkes", p. 54.

\section{References}

Adorno, Theodor W. Ästhetische Theorie. Frankfurt am Main 1970.

Bernstein, J.M. The Fate of Art. Aesthetic Alienation from Kant to Derrida and Adorno. Pennsylvania 1992.

Boehm, Gottfried. "Im Horizont der Zeit. Heideggers Werksbegriff und die Kunst der Moderne", in Kunst und Technik, ed. Walter Biemel and Friedrich-Wilhelm v. Herrmann. Frankfurt am Main 1989, 255-286.

Derrida, Jacques. La vérité en peinture. Paris 1978. German trans. Die Wahrheit in der Malerei, second ed. Wien 2008.

Gadamer, Hans-Georg. "Zur Einführung”, in Martin Heidegger, Der Ursprung des Kunstwerks. Stuttgart 1960, 93-114.

Gadamer, Hans-Georg. Kunst als Aussage. Gesammelte Werke, Bd. 8, Tübingen 1993.

Haugeland, John. "Truth and Finitude: Heidegger's Transcendental Existentialism", in Heidegger, Authenticity, and Modernity, ed. Mark Wrathall and Jeff Malpas. Cambridge Mass. 2000, 43-77.

Heidegger, Martin. Der Ursprung des Kunstwerkes, in M. Heidegger, Gesamtausgabe Bd. 5 (=GA 5).

Kern, Andrea. “'Der Ursprung des Kunstwerkes'. Kunst und Wahrheit zwischen Stiftung und Sreit", in Heidegger-Handbuch. Leben - Werk - Wirkung, ed. D. Thomä. Stuttgart 2003.

Lacoue-Labarthe, Philippe. La Fiction du Politique. Heidegger, L'art et la politique. Paris 1987. German trans. Die Fiktion des Politischen. Heidegger, die Kunst und die Politik. Stuttgart 1990.

Menke, Christoph. Die Souveränität der Kunst. Ästhetische Erfahrung nach Adorno und Derrida [1988]. Frankfurt am Main 1991.

Pöggeler, Otto. Die Frage nach der Kunst. Von Hegel zu Heidegger. Freiburg 1984. Rorty, Richard. "Heidegger wider die Pragmatisten", Neue Hefte für Philosophie 23 (1984), 1-22.

Schapiro, Meyer. "The Still Life as a Personal Object. A Note on Heidegger and van Gogh", in The Reach of Mind, ed. Marianne L. Simmel. New York 1968, 203-209. 